\title{
A comparative study of immunocapture ELISA and RT-PCR for screening clinical samples from Southern Greece for human influenza virus types $A$ and $B$
}

\author{
ELIAS PLAKOKEFALOS**, PANAYOTIS MARKOULATOS*, EUTYCHIOS KTENAS ${ }^{*}$, NIKI SPYROU* \\ and NICHOLAS C. VAMVAKOPOULOS: \\ *National Influenza Center, Southern Greece, Virology Department, Hellenic Pasteur Institute, 127 Vas. Sofias \\ Avenue, Athens 115 21, †National School of Public Health, 196 Alexandras Avenue, Athens 11521 and \\ Department of Biology and Genetics, University of Thessaly Medical School, 22 Papakyriazi Street, Larisa \\ 41222, Thessaly, Greece
}

\begin{abstract}
An immunocapture (IC) ELISA and reverse transcriptase (RT)-PCR assays were evaluated as screening methods for the detection of influenza virus types $A$ and $B$ in clinical samples collected from individuals presenting with influenza-like symptoms in Southern Greece. Standard virus isolation in embryonated hens' eggs was taken as the reference method. According to the reference method, 25 (16.7\%) of the 150 clinical samples examined were infected by influenza viruses - 19 type A (H3N2) and 6 type B. The sensitivity of immunocapture ELISA was $64 \%$ and that for RT-PCR was $100 \%$. The specificity of IC ELISA was $98 \%$ and by RT-PCR $97 \%$. The positive diagnostic value of IC ELISA was 94\% and of RT-PCR $86 \%$, whereas the negative diagnostic values for IC ELISA and PCR were $93 \%$ and $100 \%$, respectively. These findings confirm that RTPCR provides significantly increased sensitivity over IC ELISA and can be of value in the management of regional influenza screening surveys conducted by the national public health services.
\end{abstract}

\section{Introduction}

Influenza virus types $\mathrm{A}$ and $\mathrm{B}$ have a single-stranded segmented RNA genome of negative polarity. Because of their high rate of mutation, they exhibit increased genetic and antigenic instability resulting in frequent antigenic drift, and in the case of type A, more rarely antigenic shift [1]. Influenza viruses are the primary cause of annual influenza epidemics. They constitute the most important and widespread pathogens of the upper and lower respiratory tract in man, causing high rates of morbidity and mortality world-wide, especially among the elderly and patients suffering from chronic cardiovascular and respiratory problems [2]. To ameliorate the impact of influenza epidemics, national public health services follow a rigorous influenza surveillance and vaccination policy, espe-

Date received 29 Nov. 1999; revised version received 30 March 2000; accepted 6 April 2000.

Corresponding author: Dr N. Spyrou

(e-mail: vresearch@hol.gr). cially for populations at high risk [3]. However, the efficacy of vaccination depends on the specific cocktail of protective antigenicities being used to maximise coverage by the most dominant viral genotypic variants being periodically identified. This sorting process requires regular surveys of influenza activity in samples collected from patients with flulike symptoms, which include high fever, head and muscle aches and general fatigue [4]. However, other human pathogens of the respiratory tract, including respiratory syncytial virus (RSV), parainfluenza virus types 1, 2, 3 and 4, adenoviruses and rhinoviruses, cause similar symptoms. This multitude of agents, in addition to influenza viruses, causing similar clinical symptoms, renders primary screening of influenzapositive patients a major task. Efficient control of influenza epidemics requires continuous optimisation of all aspects of vaccine development and administration including painstaking assessment of its efficacy. Effective monitoring of viral outbreaks involves the implementation of numerous screening methods of influenza activity, including virus isolation from embryonated hens' eggs and tissue culture, immunofluorescence $[5,6]$, enzyme immunoassays (ELISA) 
[7, 8], reverse transcriptase (RT)-PCR $[9,10]$, multiplex RT-PCR $[6,11]$ and PCR coupled to enzyme immunoassay $[12,13]$. A number of investigators have evaluated most of these methods and have assessed their sensitivities, specificities, diagnostic values and false positive or negative results, in an attempt to normalise and compare the large variety of influenza surveys conducted world-wide every year [14-18].

The present study compared the performance characteristics of immunocapture (IC) ELISA and RT-PCR as screening methods for influenza virus type $\mathrm{A}$ and $\mathrm{B}$ activities. It reports the sensitivity, specificity, diagnostic value, false positive or negative results of each method in detecting and identifying influenza infection directly from the clinical specimens and after passage to embryonated hens' eggs; virus isolation was the method of reference or 'gold standard'.

\section{Materials and methods}

\section{Clinical specimens}

The 150 nasal and pharyngeal swabs or primary samples were collected from individuals with influenza-like illness, 3-4 days following the onset of symptoms. All primary samples were collected during two World Health Organization (WHO) influenza surveillance periods, from Oct. 1996 to April 1997 and from Oct. 1997 to April 1998. Patients' ages ranged from 20 days to 65 years. Specimen collections were from out-patient facilities of hospitals and private practice physicians in Southern Greece. All samples were held in $2.5 \mathrm{ml}$ of virus transport medium containing (/L) bacto-tryptose $24.9 \mathrm{~g}$, gelatin $5 \mathrm{~g}$, streptomycin $0.5 \mathrm{~g}$, penicillin $500000 \mathrm{U}$ and fungizone $50 \mathrm{mg}$, at $4^{\circ} \mathrm{C}$ for 2 days. The swabs were removed from the vials and the clinical specimens were centrifuged at $1500 \mathrm{~g}$ at $4^{\circ} \mathrm{C}$ for $15 \mathrm{~min}$. The supernates were either tested immediately, or stored at $-80^{\circ} \mathrm{C}$.

\section{Influenza virus propagation and typing}

All primary samples and negative controls were inoculated into the amniotic $(150 \mu \mathrm{l})$ and allantoic $(150 \mu \mathrm{l})$ cavities of 8-day-old embryonated hens' eggs and incubated at $35^{\circ} \mathrm{C}$ for 3 days. Propagated samples were the primary samples that had been passed in embryonated hens' eggs. After incubation, amniotic and allantoic fluids were harvested and viral titres were determined by the haemagglutination (HA) test with chicken red blood cells $0.5 \%$, according to standard WHO protocols. All isolates were typed by the haemagglutination-inhibition (HI) method as type A, subtype $\mathrm{H} 1 \mathrm{~N} 1$ and $\mathrm{H} 3 \mathrm{~N} 2$, or type B with antisera and guidelines provided by WHO for the surveillance of influenza.

\section{Immunocapture ELISA}

The primary samples were screened by IC ELISA, and typed as influenza type A or B with monoclonal antibodies (MAbs) raised against the respective viral nucleoproteins. ELISA microplates (Greiner Laboratories, Germany) were coated $(100 \mu \mathrm{l} /$ well $)$ with solutions of polyclonal antibodies raised in rabbits against influenza type A or B specific antigens (kindly provided by Professor S. van der Werf, Institut Pasteur, Paris, France), which had been diluted 1 in 6000 in $0.05 \mathrm{M}$ carbonate-bicarbonate buffer (pH 9.6). Polyclonal antibodies were adsorbed to plastic surface at $4^{\circ} \mathrm{C}$ overnight. After each step of the IC ELISA, plates were washed five times with phosphate-buffered saline (PBS) containing Tween-20 $0.05 \%$. Non-specific binding was eliminated by the addition of $100 \mu \mathrm{l}$ of saturation buffer containing gelatin (Merck) $0.5 \%$ in $0.05 \mathrm{M}$ carbonate-bicarbonate buffer $(\mathrm{pH} 9.6)$ to each well, followed by incubation at $37^{\circ} \mathrm{C}$ for $1 \mathrm{~h}$. Each ELISA microplate contained duplicate positive control wells consisting of $100 \mu \mathrm{l}$ of allantoic fluids infected with influenza type A or B of known HA titre diluted in PBS-bovine serum albumin (BSA) $1 \%$ containing, Tween-20 0.1\%, and duplicate wells containing $100 \mu \mathrm{l}$ of uninfected allantoic fluids as negative controls. Unknown samples were added in duplicate at $100 \mu \mathrm{l} /$ well and incubated at $37^{\circ} \mathrm{C}$ for $1 \mathrm{~h}$. Anti-A or anti-B influenza mouse MAbs (WHO Influenza Reference Center, CDC, Atlanta, USA), diluted 1 in 1250 in PBS containing BSA $1 \%$ and Tween-20 $0.1 \%$ were added $(100 \mu \mathrm{l})$ to the wells. The plates were incubated for $30 \mathrm{~min}$ at $37^{\circ} \mathrm{C}$ and $100 \mu \mathrm{l}$ of biotinylated anti-mouse antibodies (BIOSYS, France) diluted 1 in 4000 in PBS containing BSA $1 \%$ and Tween- $200.1 \%$ were added to each well. After incubation at $37^{\circ} \mathrm{C}$ for $30 \mathrm{~min}, 100 \mu \mathrm{l}$ of horseradish peroxidase-avidin D conjugate (Vector Laboratories, CA) diluted 1 in 5000 in PBS containing BSA $1 \%$ and Tween- $200.1 \%$ were added to each well. The plates were incubated at $37^{\circ} \mathrm{C}$ for $10 \mathrm{~min}$. Finally, $100 \mu \mathrm{l}$ of substrate solution containing $10 \mathrm{mg} o$ phenylene diaminehydrochloride in $25 \mathrm{ml}$ of $0.1 \mathrm{M}$ citrate-phosphate buffer $\left(\mathrm{pH}\right.$ 5) and $0.03 \% \mathrm{H}_{2} \mathrm{O}_{2}$ were added immediately before use to each well and the plates were incubated in the dark at room temperature for $30 \mathrm{~min}$, at which time the reaction was stopped by the addition of $3 \mathrm{~N} \mathrm{HCl} 100 \mu \mathrm{l} /$ well. The absorbance was measured at $492 \mathrm{~nm}$ and $630 \mathrm{~nm}$ in a Dynatech ELISA microplate reader MR 5000 (Dynatech Laboratories, VA, USA). The positive cut-off was adjusted to 0.3 OD units, as all the negative controls gave an OD value $<0.3$ units. All samples with $\mathrm{OD}$ values above the positive cut-off were considered positive and those with OD values under this cut-off were considered negative.

\section{Viral RNA extraction and cDNA synthesis}

Viral RNA was extracted from $250-\mu 1$ portions of either the primary samples or the infected allantoic or 
amniotic fluids, or both, with TRIzol (Gibco BRL, Life Technologies, NY, USA), according to the manufacturer's recommendations. Type A (H1N1) and (H3N2) and type $\mathrm{B}$ isolates previously identified by the WHO Influenza Reference Center in London served as positive controls; while uninfected allantoic fluids served as negative controls. For cDNA synthesis, $5 \mu \mathrm{l}$ of extracted viral RNA were incubated at $70^{\circ} \mathrm{C}$ for 5 min with $2.5 \mu \mathrm{l}$ of random hexanucleotide primers $(40 \mu \mathrm{g} / \mu \mathrm{l})$ (New England Biolabs, MA, USA) and RNasin (Promega, WI, USA) $20 \mathrm{U} / \mu \mathrm{l}$, quenched on ice and then $5 \mu \mathrm{l}$ of $5 \times$ reaction buffer (Promega), MMLV reverse transcriptase (Promega) $100 \mathrm{U} /$ tube, $5 \mu \mathrm{l}$ of $10 \mathrm{mM}$ solution of the four deoxynucleotide triphosphates (Promega) and sterile $\mathrm{H}_{2} \mathrm{O}$ (Sigma) were added to give a $25-\mu 1$ final volume. The reactions were incubated at $37^{\circ} \mathrm{C}$ for $1 \mathrm{~h}$ and at $95^{\circ} \mathrm{C}$ for $5 \mathrm{~min}$ in a Techne Progene thermal cycler. The reaction product was stored at $-20^{\circ} \mathrm{C}$.

\section{Nested PCR}

Influenza viruses were typed as A or B by nested PCR with primers that amplified a highly conserved region of the internal viral matrix protein gene [19]. Type A viruses were further subtyped with HA1, HA2 and HA3 as well as NA1 and NA2 specific primers that hybridise to conserved regions of the haemagglutinin and neuraminidase genes of influenza, respectively [19]. The sensitivity and specificity of the primer pairs in the nested PCR have been reported [19]. Nested PCR took place in two consecutive amplifications. The first amplification reaction contained $5 \mu \mathrm{l}$ of $10 \times$ reaction buffer (Minotech, Crete, Greece), $4 \mu \mathrm{l}$ of a $10 \mathrm{~mm}$ solution of the four deoxynucleotide triphosphates (Promega), 2 units of Taq DNA Polymerase (Minotech), $2 \mu \mathrm{l}$ of $25 \mathrm{mM} \mathrm{MgCl}_{2}, 4 \mu \mathrm{l}$ of cDNA, 200 pmoles of the outer primers and sterile $\mathrm{H}_{2} \mathrm{O}$ to $50 \mu \mathrm{l}$ total volume. The reactions were amplified in a Techne Progene Thermal Cycler for 25 cycles of denaturation at $94^{\circ} \mathrm{C}$ for $10 \mathrm{~s}$, annealing at $50^{\circ} \mathrm{C}$ for $10 \mathrm{~s}$ and elongation at $72^{\circ} \mathrm{C}$ for $30 \mathrm{~s}$. Two $\mu \mathrm{l}$ of the first PCR amplification were added to a second PCR reaction containing the inner pair of primers and amplified for 40 cycles under the same cycling conditions. Amplification products were analysed by agarose (Gibco
BRL, Ultra Pure agarose, electrophoresis grade) $2 \%$ gel electrophoresis in $1 \times$ TBE buffer, stained with ethidium bromide $1 \mu \mathrm{g} / \mathrm{ml}$ and visualised with a UV transilluminator (Foto/Phoresis, Fotodyne, WI, USA).

\section{Statistical analysis}

The SPSS statistical package was used to analyse the data generated in this study. Differences between the two screening methods were determined by the $\chi^{2}$ test.

\section{Results}

Tables 1-5 summarise the study findings. More specifically, screening 150 primary samples which had been propagated in embryonated hens' eggs by the HI method, revealed that $25(16.7 \%)$ were infected by influenza viruses, $19(76 \%)$ with type A (H3N2) and 6 (24\%) with type B strains. Screening the same primary samples by IC ELISA revealed $17(11.3 \%)$ cases infected with influenza virus, 13 (76.4\%) of which were type A and $4(30.7 \%)$ type B. Eight additional samples were found to be influenza positive, six with type A and two with type B strains, by IC ELISA after three passages of the primary samples in embryonated hens' eggs. Of the 25 samples positive by IC ELISA, $24(96 \%)$ were positive for influenza infection by the reference method. One primary sample that was positive by IC ELISA did not yield a positive result after three passages in eggs. Thus, IC ELISA underestimated influenza positive primary samples, relative to the reference method. It follows from the results that propagated samples contained a higher concentration of

Table 1. Influenza virus detection by virus isolation, IC ELISA and RT-PCR

\begin{tabular}{|c|c|c|}
\hline \multirow[b]{2}{*}{ Method } & \multicolumn{2}{|c|}{$\begin{array}{c}\text { Number }(\%) \text { of samples } \\
(\mathrm{n}=150)\end{array}$} \\
\hline & Positive & Negative \\
\hline Virus isolation & $25(16.7)$ & $125(83.3)$ \\
\hline IC ELISA on primary samples & $17(11.3)$ & $133(88.7)$ \\
\hline IC ELISA on propagated samples & $25(16.7)$ & $125(83.3)$ \\
\hline RT-PCR on primary samples & $29(19.3)$ & $121(80.7)$ \\
\hline RT-PCR on propagated samples & $29(19.3)$ & $121(80.7)$ \\
\hline
\end{tabular}

Table 2. Detection of influenza virus in primary samples by virus isolation, IC ELISA and RT-PCR

\begin{tabular}{|c|c|c|c|c|c|}
\hline \multirow[b]{2}{*}{ Method } & & \multirow{2}{*}{$\begin{array}{c}\text { Number } \\
\text { of } \\
\text { samples }\end{array}$} & \multicolumn{3}{|c|}{ Number (\%) with equivalent result by } \\
\hline & & & $\begin{array}{l}\text { Virus } \\
\text { isolation }\end{array}$ & IC ELISA & RT-PCR \\
\hline \multirow{2}{*}{$\begin{array}{l}\text { Virus } \\
\text { isolation }\end{array}$} & positive & 25 & $\ldots$ & $16(64)$ & $25(100)$ \\
\hline & negative & 125 & $\ldots$ & $125(100)$ & $121(96.8)$ \\
\hline \multirow[t]{2}{*}{ IC ELISA } & positive & 17 & $16(64)$ & $\ldots$ & $17(100)$ \\
\hline & negative & 133 & $125(94)$ & $\ldots$ & $121(91)$ \\
\hline \multirow[t]{2}{*}{ RT-PCR } & positive & 29 & $25(86.2)$ & $17(58.6)$ & $\ldots$ \\
\hline & negative & 121 & $121(100)$ & $121(100)$ & \\
\hline
\end{tabular}


Table 3. Year 1 influenza identifications by virus isolation, IC ELISA and RT-PCR

\begin{tabular}{lcl}
\hline & \multicolumn{1}{c}{ Number $(\%)$ of samples $(\mathrm{n}=70)$} \\
\cline { 2 - 3 } Method & Positive & Negative \\
\hline Virus isolation & $11(15.7)$ & $59(84.3)$ \\
IC ELISA on primary samples & $7(10)$ & $63(90)$ \\
IC ELISA on propagated & $11(15.7)$ & $59(84.3)$ \\
samples & $13(18.6)$ & $57(81.4)$ \\
RT-PCR on primary samples & $13(18.6)$ & $57(81.4)$ \\
RT-PCR on propagated samples & & \\
\hline
\end{tabular}

Table 4. Year 2 influenza identifications by virus isolation, IC ELISA and RT-PCR

\begin{tabular}{lll}
\hline & \multicolumn{1}{c}{$\begin{array}{c}\text { Number }(\%) \text { of samples } \\
(\mathrm{n}=80)\end{array}$} \\
\cline { 2 - 3 } Method & \multicolumn{1}{c}{ Positive } & Negative \\
\hline Virus isolation & $14(17.5)$ & $66(82.5)$ \\
IC ELISA on primary samples & $10(12.5)$ & $70(87.5)$ \\
IC ELISA on propagated samples & $14(17.5)$ & $66(82.5)$ \\
RT-PCR on primary samples & $16(20)$ & $64(80)$ \\
RT-PCR on propagated samples & $16(20)$ & $64(80)$ \\
\hline
\end{tabular}

virus particles that were detected by IC ELISA, increasing the number of overall positive results found by that method. Screening the same 150 clinical specimens before and after propagation in embryonated hens' eggs by RT-PCR revealed 29 (19.3\%) infected by influenza viruses, $22(75.8 \%)$ with type A subtype H3N2 and 7 (24\%) with type B strains. All samples that were influenza positive by virus isolation were also positive by RT-PCR. There was $100 \%$ correlation in the type and subtype of influenza-positive samples determined by RT-PCR and virus isolation. RT-PCR detected four additional positive samples in the primary samples, three type A (H3N2) and one type B, compared with virus isolation. These PCR-positive samples were negative after three passages in eggs. One of the three A (H3N2) samples which was positive by PCR was found to be positive by IC ELISA on the primary samples. These findings are summarised in Tables 1 and 2. Tables 3 and 4 show the number of positive and negative influenza detections by the three methods for the first and second year of surveillance, respectively. Table 5 compares the sensitivities and specificities as well as the diagnostic values and false positive and negative results in IC ELISA and RT-PCR with primary or propagated samples. There was a statistically significant difference $(\mathrm{p}<0.001)$ between IC ELISA (64\%) and RT-PCR (100\%) in the sensitivity of influenza detection in the primary samples.

\section{Discussion}

Most of the methods frequently used to screen for influenza infection, such as ELISA and immunofluorescence (IF), require propagated clinical material for sensitive, specific and reliable viral detection. Recently developed RT-PCR methods offer increased sensitivity for direct influenza virus detection, typing and subtyping in primary clinical specimens $[6,10,18]$; thus obviating the need to propagate the virus in embryonated hens' eggs or tissue culture. RT-PCR has been shown to have increased sensitivity over ELISA and IF for influenza detection in clinical samples [6, 18]; this facilitates early administration of antiviral treatment and has a beneficial role in the overall management of influenza epidemics [17]. A weakness of RT-PCR is the ease with which minor contamination may yield falsepositive results, a possibility that is even more pronounced with nested PCR methods.

In the present study, RT-PCR detected four more influenza-positive samples than virus isolation in eggs. This discrepancy of RT-PCR relative to the reference method may have derived from the potential presence of inactive viruses in the clinical sample, which are usually undetectable by virus isolation methods. This loss of virus viability is possibly due to prolonged storage of samples under non-ideal temperature conditions before arrival at the laboratory or the presence of partially inactivated virus in the clinical sample, or both [17, 19]. Compared with RT-PCR, IC ELISA had lower sensitivity for the detection of influenza infection directly from primary clinical samples [17, 18]. IC ELISA detected 17 influenza viruses in primary samples (as compared with 29 by RT-PCR), and 25 in propagated samples, 24 of which were identified as influenza virus-positive by the reference virus isolation method. This increase in IC ELISA sensitivity following viral propagation demonstrates the dependence of the method on the viral titre. IC ELISA detected one influenza-positive sample, which was also positive by

Table 5. Sensitivity, specificity, diagnostic value and false positive and negative values for IC ELISA and RT-PCR

\begin{tabular}{|c|c|c|c|c|c|c|}
\hline \multirow[b]{2}{*}{ Method } & \multirow[b]{2}{*}{ Sensitivity $(\%)$} & \multirow[b]{2}{*}{ Specificity $(\%)$} & \multicolumn{2}{|c|}{ Diagnostic value (\%) } & \multicolumn{2}{|c|}{ False } \\
\hline & & & positive & negative & positive $(\%)$ & negative $(\%)$ \\
\hline IC ELISA on primary samples & 64 & 98.4 & 94.1 & 92.5 & 5.9 & 7.5 \\
\hline IC ELISA on propagated samples & 100 & 100 & 100 & 100 & 0 & 0 \\
\hline RT-PCR on primary samples & 100 & 96.8 & 86.2 & 100 & 13.8 & 0 \\
\hline RT-PCR on propagated samples & 100 & 96.8 & 86.2 & 100 & 13.8 & 0 \\
\hline
\end{tabular}

Sensitivity: true positives the sum of influenza positive samples according to the reference method. Specificity: true negatives the sum of influenza negative samples according to the reference method. Positive diagnostic value: true positives/true positives + false positives. Negative diagnostic value: true negatives/true negatives + false negatives. 
RT-PCR but was negative after propagation in eggs, suggesting the presence of inactive virus in the sample. It is concluded that, when used as a screening method for influenza detection, RT-PCR offers a significant advantage over IC ELISA because of its superior sensitivity and its ability to detect influenza infection even when viral inactivation has taken place. However, viral isolation in eggs or tissue culture and subsequent strain identification is pivotal in the yearly surveillance of influenza, as it enables antigenic analysis of the isolated virus and contributes to the yearly recommendation of the WHO for the influenza vaccine.

\section{References}

1 Webster RG, Bean WJ, Gorman OT, Chambers TM, Kawaoka Y. Evolution and ecology of influenza A viruses. Microbiol Rev 1992; 56: $152-179$.

2. Sprenger MJW, Mulder PGH, Beyer WEP, Van Strik R, Masurel N. Impact of influenza on mortality in relation to age and underlying disease, 1967-1989. Int J Epidemiol 1993; 22: $334-340$.

3. Hannoun C. Role of international networks for the surveillance of influenza. Eur J Epidemiol 1994; 10: 459-461.

4. Cate TR. Clinical manifestations and consequences of influenza. Am J Med 1987; 82: 15-19.

5. Spada B, Bielher K, Chegas P, Kaye J, Riepenhoff-Talty M. Comparison of rapid immunofluorescence assay to cell culture isolation for the detection of influenza A and B viruses in nasopharyngeal secretions from infants and children. $J$ Virol Methods 1991; 33: 305-310.

6. Ellis JS, Fleming DM, Zambon MC. Multiplex reverse transcription-PCR for surveillance of influenza A and B viruses in England and Wales in 1995 and 1996. J Clin Microbiol 1997; 35: 2076-2082.

7. Chomel JJ, Thouvenot D, Onno M, Kaiser C, Gourreau JM, Aymard M. Rapid diagnosis of influenza infection of NP antigen using an immunocapture ELISA test. $J$ Virol Methods 1989; 25: 81-91.
8. Duverlie G, Houbart L, Visse B et al. A nylon membrane enzyme immunoassay for rapid diagnosis of influenza A infection. J Virol Methods 1992; 40: 77-84.

9. Claas ECJ, van Milaan AJ, Sprenger MJW et al. Prospective application of reverse transcriptase polymerase chain reaction for diagnosing influenza infections in respiratory samples from a children's hospital. J Clin Microbiol 1993; 31; 2218-2221.

10. Wright KE, Wilson GAR, Novosad D, Dimock C, Tan D, Weber JM. Typing and subtyping of influenza viruses in clinical samples by PCR. J Clin Microbiol 1995; 33: 11801184.

11. Stockton J, Ellis JS, Saville M, Clewley JP, Zambon MC. Multiplex PCR for typing and subtyping influenza and respiratory syncytial viruses. J Clin Microbiol 1998; 36: 2990-2995.

12. Cherian T, Bobo L, Steinhoff MC, Karron RA, Yolken RH. Use of PCR-enzyme immunoassay for identification of influenza A virus matrix RNA in clinical samples negative for cultivable virus. J Clin Microbiol 1994; 32: 623-628.

13. Schweiger B, Lange I, Heckler R, Willers H, Schreier E. Rapid detection of influenza A neuraminidase subtypes by cDNA amplification coupled to a simple DNA enzyme immunoassay. Arch Virol 1994; 139: 439-444.

14. Atmar RL, Baxter BD, Dominguez EA, Taber LH. Comparison of reverse transcription-PCR tissue culture and with other rapid diagnostic assays for detection of type A influenza virus. $J$ Clin Microbiol 1996; 34: 2604-2606.

15. Chomel JJ, Remilleux MF, Marchand P, Aymard M. Rapid diagnosis of influenza A. Comparison with ELISA immunocapture and culture. J Virol Methods 1992; 37: 337-344.

16. Waner JL, Todd SJ, Shalaby H, Murphy P, Wall LV. Comparison of Directigen FLU-A with viral isolation and direct immunofluorescence for the rapid detection and identification of influenza A virus. J Clin Microbiol 1991; 29: 479-482.

17. Pregliasco F, Mensi C, Camorali L, Anselmi G. Comparison of RT-PCR with other diagnostic assays for rapid detection of influenza viruses. J Med Virol 1998; 56: 168-173.

18. Magnard C, Valette M, Aymard M, Lina B. Comparison of two nested PCR, cell culture, and antigen detection for the diagnosis of upper respiratory tract infections due to influenza viruses. J Med Virol 1999; 59: 215-220.

19. Zhang W, Evans DH. Detection and identification of human influenza viruses by the polymerase chain reaction. $J$ Virol Methods 1991; 33: 165-189. 